\title{
IDENTIFYING THE SOURCE OF POLLUTANTS IN MALACCA RIVER USING GIS APPROACH
}

\author{
HUA, A. K. \\ Department of Environmental Sciences, Faculty of Environmental Studies, \\ Universiti Putra Malaysia, 43400 UPM Serdang, Selangor, Malaysia \\ e-mail:angkeanhua@yahoo.com \\ (Received 19 $9^{\text {th }}$ Mar 2017; accepted $26^{\text {th }}$ Jun 2017)
}

\begin{abstract}
The study was conducted to determine the dominant source of pollutants in Malacca River using the combined methods of water sampling and GIS approach. The study was conducted in 9 sampling stations based on Malacca River sub-basins. The result of WQI indicated that station 4 and 5 are polluted; station 8 and 9 are clean; and other stations are slightly polluted. PCA identified several pollutant sources, namely agricultural, residential, industrial, animal husbandry activities, as well as sewage treatment plants. Applied GIS technique detected several areas as hotspots pollutants sources, namely agricultural activities in station 5; residential activities in station 1,2,5, 6, and 7; industrial activities in station 3, 4, 5, and 7; animal husbandry in station 5 and some scatterings in station 1 to 4 ; as well as sewage treatment plant in moderate hotspot area between station 5 and 6 , respectively. Besides the recommendation to reduce the river water pollution through the control of pollutants source, this study provides crucial information for the identification of problematic areas and spatial database of Malacca River for better understanding and management of river water quality in the future, as well as a reference for future land use and urban design development purposes.
\end{abstract}

Keywords: WQI, PCA, hotspot analysis, spatial database

\section{Introduction}

River water pollution has received great attention in recent years and continues to receive serious concern throughout the world. Water quality deterioration is primarily connected to the subject of population growth and city expansion. This is a threatening factor to human and ecological health, drinking water availability, and furthermore to the economic development (Houser and Richardson, 2015; Morse and Wolheim, 2014; $\mathrm{Li}$ and Zhang, 2010). According to Iscen et al. (2008), surface water is easily exposed to pollution due to its - accessibility to wastewater disposal. Water quality impairment resulted from anthropogenic inputs (e.g. municipal and industrial wastewater discharges, agricultural runoff) and natural processes such as chemical weathering and soil erosion (Shin et al., 2013; Singh et al., 2011; Iscen et al., 2008), contributed to the input of non-point and point source pollutants of the river (Iscen et al., 2008). Therefore, water quality assessment with geographic information system (GIS) is an important tool in identifying possible pollutant sources with the aim to prevent and control water pollution; which is crucial for sustainable water resource use with respect to ecosystem health and social development (Iscen et al., 2008; Shrestha and Kazama, 2007; Zhang, 2006).

Malaysia as an ongoing developing country in South East Asia is facing major water quality problems (DOE, 2012). Human activities that generate economic benefit for the society has indirectly deteriorate the water quality of the river (Muyibi et al., 2008). Several studies focused on the assessment of water quality indicated that unsustainable development could result in environmental damage to surrounding areas, as well as to the biodiversity of benthic macroinvertebrates (Al-Shami et al., 2010). Specifically, 
researchers have identified that wastewater that were discharged from the manufacturing and agro-based industry, domestic sewage, animal husbandry, mining activity, and surface runoff originating from land clearing and earthwork activity; could lead to water resource pollution, especially in the river (DOE, 2012; Suratman et al., 2009; Deb et al., 2008; Ebrahimpour and Mushrifah, 2008; Muyibi et al., 2008).

This situation is no stranger to the state of Malacca, which has faced serious water pollution problems that led to the death of aquatic species along the Malacca River (Sinar Harian Online, 2016; Hua, 2015; Metro Online, 2015; Daneshmend et al., 2011). Malacca State was recognized by UNESCO as a World Heritage Site in 2008 (UNESCO, 2016) and since has become a world historical tourism center for the country. This establishment is important for the economic and population growth of Malacca State. Indirectly, Malacca River may not have been exposed to the issues of river water pollution in the past. Nevertheless, the increasing number of population, uncontrolled rapid development, and extreme land use has led to the 'disruption' of Malacca River. Besides water quality assessment and monitoring, an applied GIS through hotspot analysis would assist in determining the dominant source of pollution that has greater impact to Malacca River. GIS hotspot analysis is a method that has been frequently applied in various studies in the fields of diseases (Liu et al., 2006), mortality rates (Mclaughlin and Boscoe, 2007), environmental planning, as well as the environmental sciences (Ishioka et al., 2007). For instant, Liu et al. (2006) used GIS to assess and sample the pattern of heavy metal in paddy field; and Zhang (2006) used hotspot analysis of GIS approach to identify the pollutants in urban soils in Ireland.

Several GIS analysis methods have been proposed for hotspot analysis, such as spatial scan statistics (Ishioka et al., 2007), Tango' C index (Zhang and Lin, 2006; Tango, 1995), as well as Getis's G index (Getis and Ord, 1992). These methods are often used in the field of environmental sciences, planning, and management. Hotspot analysis which is extended from Moran's I index in spatial analysis, can be classified into two categories, namely global Moran's I (Oldland, 1998; Cliff and Ord, 1981) and local Moran's I index (Zhang et al., 2008; Mclaughlin and Boscoe, 2007; Getis and Ord, 1992). Unlike the particular analysis of Moran's I which only focuses on the detection of similar value clusterings, hotspot analysis technique using G-statistic has the ability to express the high/low value clusterings (Getis and Ord, 1992). This technique of hotspot analysis is applied to this study. The objectives of the study are (1) to identify water quality status and pollution sources using relationship elements of natural origins; and (2) to determine the dominant sources of pollutants through spatial pattern analysis.

\section{Materials and Methods}

\section{Study Area}

The state of Malacca is located in the southwest of Peninsular Malaysia with the geographical coordinates of $2^{\circ} 23^{\prime} 16.08^{\prime \prime} \mathrm{N}$ to $2^{\circ} 24^{\prime} 52.27^{\prime} \mathrm{N}$ latitude and $102^{\circ} 10^{\prime} 36.45^{\prime \prime} \mathrm{E}$ to $102^{\circ} 29^{\prime} 17.68^{\prime} \mathrm{E}$ longitude. Malacca is divided into three districts, namely Alor Gajah, Jasin, and Malacca Central. Total catchment area of Malacca is approximately around $670 \mathrm{~km}^{2}$ with about $80 \mathrm{~km}$ distance of Malacca River. The basin is formed by 13 sub-basins namely Kampung Ampang Batu Gadek sub-basin, Kampung Balai sub-basin, Kampung Batu Berendam sub-basin, Kampung Buloh China sub-basin, Kampung Cheng sub-basin, Kampung Gadek sub-basin, Kampung Harmoni Belimbing Dalam sub-basin, Kampung Kelemak sub-basin, Kampung Panchor sub-basin, 
Kampung Pulau sub-basin, Kampung Sungai Petai sub-basin, Kampung Tamah Merah sub-basin, and Kampung Tualang sub-basin (Figure 1). Among the 13 sub-basins, only 7 sub-basins were selected, with 9 sampling stations located alongside Malacca River.

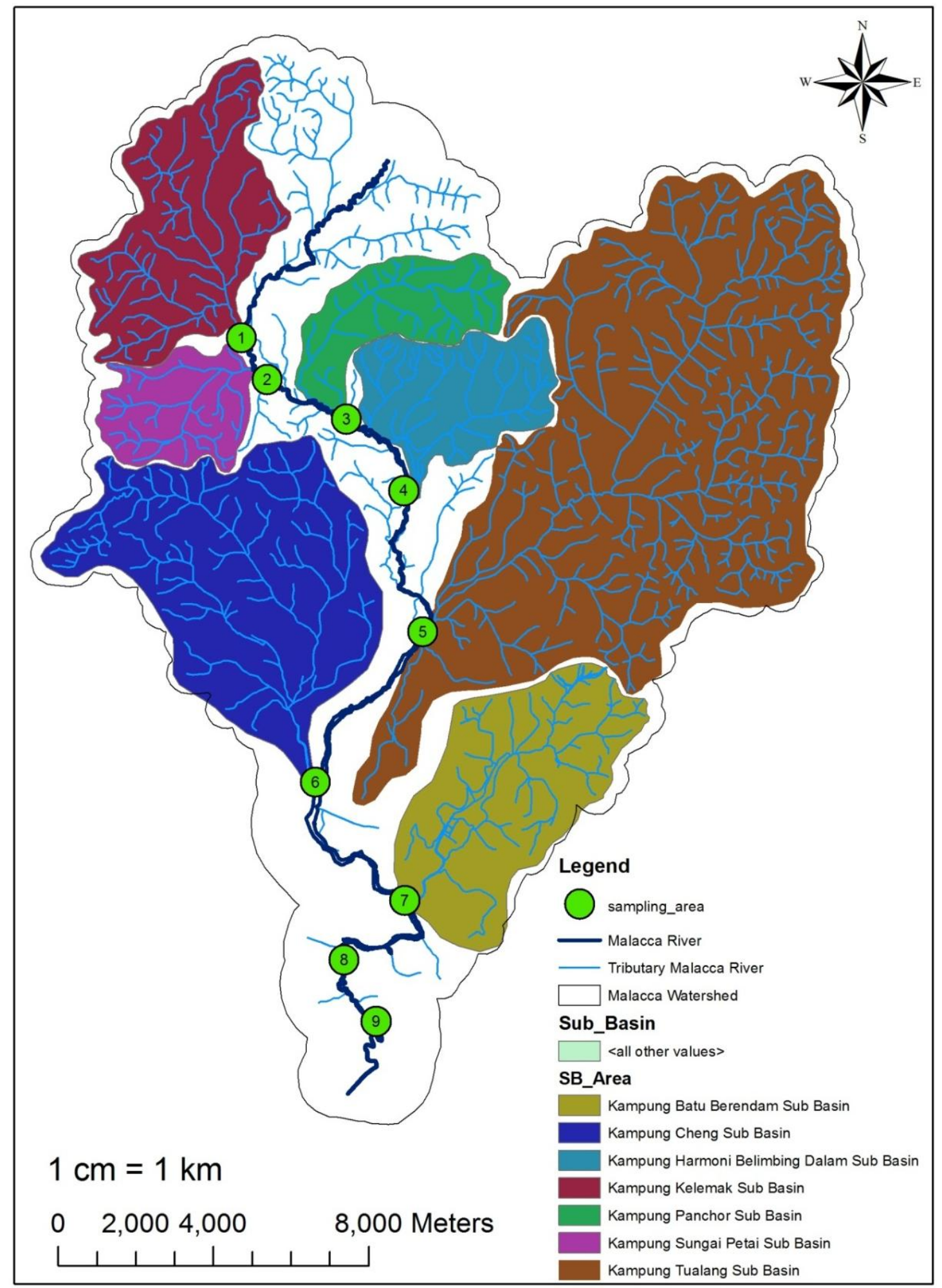

Figure 1. Malacca River sub-basin and sampling area 
Malacca River flows across Alor Gajah to the Malacca Central district before entering into the Straits of Malacca. Alongside Malacca River, there is a reservoir located between Alor Gajah and Malacca Central, namely Durian Tunggal Reservoir, with a catchment area of approximately $20 \mathrm{~km}^{2}$ that act as a source of water supply for Malacca residents. The built-up area is mainly concentrated in the city center, Malacca Central, at a downstream area extending about $10 \mathrm{~km}$ to the west, $10 \mathrm{~km}$ to the east, and $20 \mathrm{~km}$ to the north. The urban land uses are primarily residential and commercial, while several industrial activities including high-technology and estates are located in the middle-stream and upstream areas. Most of the large-scale agricultural activities land use are located upstream.

\section{Field Sampling}

There were 9 sampling stations chosen alongside Malacca River. The locations were determined using a Global Positioning System (GPS) coordinates as shown in Table 1 and the geographic coverage is as shown in Figure 1. The collection of water quality samples were carried out monthly from January to December 2015.

Table 1. The latitude and longitude of sampling stations

\begin{tabular}{|c|c|c|}
\hline Station & Latitude & Longitude \\
\hline S1 & $02^{\circ} 21^{\prime} 57.41^{\prime \prime} \mathrm{N}$ & $102^{\circ} 13^{\prime} 7.10^{\prime \prime} \mathrm{E}$ \\
\hline S2 & $02^{\circ} 21^{\prime} 30.16^{\prime \prime} \mathrm{N}$ & $102^{\circ} 13^{\prime} 18.20^{\prime \prime} \mathrm{E}$ \\
\hline S3 & $02^{\circ} 20^{\prime} 49.52^{\prime \prime} \mathrm{N}$ & $102^{\circ} 14^{\prime} 36.44^{\prime \prime} \mathrm{E}$ \\
\hline S4 & $02^{\circ} 19^{\prime} 41.70^{\prime \prime} \mathrm{N}$ & $102^{\circ} 15^{\prime} 27.30^{\prime \prime} \mathrm{E}$ \\
\hline S5 & $02^{\circ} 17^{\prime} 48.86^{\prime \prime} \mathrm{N}$ & $102^{\circ} 15^{\prime} 39.51^{\prime \prime} \mathrm{E}$ \\
\hline S6 & $02^{\circ} 15^{\prime} 46.55^{\prime \prime} \mathrm{N}$ & $102^{\circ} 14^{\prime} 10.72^{\prime \prime} \mathrm{E}$ \\
\hline S7 & $02^{\circ} 14^{\prime} 5.02^{\prime \prime} \mathrm{N}$ & $102^{\circ} 15^{\prime} 24.67^{\prime \prime} \mathrm{E}$ \\
\hline S8 & $02^{\circ} 13^{\prime} 14.33^{\prime \prime} \mathrm{N}$ & $102^{\circ} 14^{\prime} 35.01^{\prime \prime} \mathrm{E}$ \\
\hline S9 & $02^{\circ} 12^{\prime} 23.42^{\prime \prime} \mathrm{N}$ & $102^{\circ} 15^{\prime} 0.80^{\prime \prime} \mathrm{E}$ \\
\hline
\end{tabular}

Source: Global Positioning System

The water samples were collected using 'grab sampling' technique in the polyethylene bottles without entrapping the air bubbles. Each bottle was labelled with the corresponding sampling station and kept at $4{ }^{\circ} \mathrm{C}$ to minimize microbial activity in the water (APHA, 2005). The water samples were analyzed for physico-chemical parameters (i.e. $\mathrm{pH}$, temperature, electrical conductivity (EC), salinity, turbidity, total suspended solid (TSS), dissolved solids (DS), dissolved oxygen (DO), biological oxygen demand (BOD), chemical oxygen demand (COD), and ammoniacal-nitrogen $\left(\mathrm{NH}_{3}-\mathrm{N}\right)$, trace metals (i.e. mercury, cadmium, chromium, arsenic, zinc, lead and iron)) and biological parameters (i.e. Escherichia coliform and total coliform). Since water sample containing colloidal or suspended particulate material could interfere with the metal analysis, the samples were immediately filtered using $0.45 \mu \mathrm{m}$ cellulose acetate membrane filter (Whatman Milipores, Clifton, NJ) at the laboratory. The purpose of this procedure was to prevent the occurrence of clogging during analysis with spectrometry instruments and to obtain the dissolved ions for metal analysis (APHA, 2005). Then, the samples were acidified with $\mathrm{HNO}_{3}$ to $\mathrm{pH}<2$ in order to prevent precipitation of the components for trace metal analysis and to retard any biological activities (APHA, 2005). 


\section{Water Quality Analysis}

The water samples were analyzed according to the procedure of APHA (2005), meaning that $\mathrm{pH}$, turbidity, EC, TDS, salinity, and DO were measured on-site. SevenGo Duo pro probe (Mettler Toledo AG) was used for the measurement of $\mathrm{pH}$ values, while turbidity was tested using the Handled Turbidimeter Hach 2100. Orion Star Series Portable Meter was used to measure temperature, EC, DS, salinity, and DO. Meanwhile, NH3N was analyzed using a spectrophotometer at a specific wavelength using Hach Method 8038, COD was measured using APHA 5220B open reflux technique; BOD was measured using APHA 5210B (or Hach Method 8043); and TSS was measured using the APHA 2540D method. Both E-coli and total coliform were analyzed using Membrane Filtration method based on APHA 9221B, and trace metals were analyzed using inductive coupled plasma-mass spectrometry (ICP-MS, ELAN DRC-e 6100, Perkin Elmer). For quality assurance and quality control purposes, laboratory apparatus and polyethylene bottles were washed using 5\% (v/v) of nitric acid and soaked overnight to remove contaminants and traces of cleaning reagent before the collection of water samples or conducting laboratory analysis.

Each sample was analyzed in triplicate before calculating the mean value, and standard deviation (SD) of less than $20 \%$ was used as an indicator of precision for each measured parameter. All the probe meters and instruments used were calibrated prior to analysis. In all cases, the standards and blank were treated in the same way as the representative river water samples to minimize matrix interference during analysis. The recovery of samples for all target elements fell within the standard requirements (90$110 \%)$.

\section{Data Analysis}

River water quality data were analyzed using Microsoft Excel and Statistical Package for Social Sciences version 19 (SPSS 19) for descriptive analysis, water quality index (WQI) and principal component analysis (PCA); to identify the water status and pollution source between elements of origin parameters, while ArcGIS version 9.3 was used to determine the dominant source of pollutants through spatial pattern analysis.

\section{Water Quality Index (WQI)}

Healthy river should have good water quality to assist with the survival of aquatic animals. The river health level is measured using WQI, which based on several parameters that need to be assessed and monitored. Different country uses different parameter to determine the WQI, whereas the Department of Environment (DOE) Malaysia using DO, BOD, COD, $\mathrm{NH}_{3} \mathrm{~N}, \mathrm{SS}$, and $\mathrm{pH}$ in determining the WQI. Generally, DO is use to measure the amount of oxygen available in water (Juahir et al., 2011); BOD determines the strength of pollutants in term of oxygen required to stabilize the wastes or measures biodegradable waste present in water (WSDE, 2002); COD measure the amount of organic and inorganic oxydizable compound in water (Davis and McCuen, 2005); SS determines the natural pollutants and causes of turbidity in water (Mathvi and Razazi, 2005); $\mathrm{NH}_{3} \mathrm{~N}$ determine the amount of ammonia exists in water that could cause eutrophication (Wang et al., 2010); and pH are to measure the acid strength in water (Davis and McCuen, 2005). Therefore, WQI for Malacca River are determined using formula that was developed by DOE (Eq.1), which consists of different sub-indexes (SIs) calculated according to the best-fit relationship (Eq.2-7): 


$$
\begin{gathered}
W Q I=0.22 * S I_{D O}+0.19 * S I_{B O D}+0.16 * S I_{C O D}+ \\
0.15 * S I_{A N}+0.16 * S I_{S S}+0.12 * S I_{p H}
\end{gathered}
$$

where WQI is water quality index; $\mathrm{SI}_{\mathrm{DO}}$ is sub-index of $\mathrm{DO}$; $\mathrm{SI}_{\mathrm{BOD}}$ is sub-index of $\mathrm{BOD}$; $\mathrm{SI}_{\mathrm{COD}}$ is sub-index of COD; $\mathrm{SI}_{\mathrm{AN}}$ is sub-index of $\mathrm{NH}_{3} \mathrm{~N}$; $\mathrm{SI}_{\mathrm{SS}}$ is sub-index of SS; $\mathrm{SI}_{\mathrm{pH}}$ is sub-index of $\mathrm{pH}$. Meanwhile, the sub-indexes (SIs) formulation is as followed (Eq.2-7);

Best-fit equations for DO sub-index:

$$
\mathrm{SI}_{\mathrm{DO}}=\left\{\begin{array}{lr}
0 & \text { for } \mathrm{DO}<8 \\
100 & \text { for } \mathrm{DO}>92 \\
-0.395+0.030 \mathrm{DO}^{2}-0.00020 \mathrm{DO}^{3} & \text { for } 8<\mathrm{DO}<92
\end{array}\right\}
$$

Best-fit equations for BOD sub-index:

$$
\mathrm{SI}_{\mathrm{BOD}}=\left\{\begin{array}{ll}
100.4-4.23 \mathrm{BOD} & \text { for } \mathrm{BOD}<5 \\
108 \mathrm{e}^{-0.055 \mathrm{BOD}}-0.1 \mathrm{BOD} & \text { for } \mathrm{BOD}>5
\end{array}\right\}
$$

Best-fit equations for COD sub-index:

$$
\mathrm{SI}_{\mathrm{COD}}=\left\{\begin{array}{ll}
-1.33 \mathrm{COD}+99.1 & \text { for } \mathrm{COD}<20 \\
103 \mathrm{e}^{-0.0157 \mathrm{COD}}-0.04 \mathrm{COD} & \text { for } \mathrm{COD}>20
\end{array}\right\}
$$

Best-fit equations for AN sub-index:

$$
\mathrm{SI}_{\mathrm{AN}}=\left\{\begin{array}{lr}
100.5-105 \mathrm{AN} & \text { for } \mathrm{AN}<0.3 \\
94 \mathrm{e}^{-0.573 \mathrm{AN}}-5|\mathrm{AN}-2| & \text { for } 0.3<\mathrm{AN}<4 \\
0 & \text { for } \mathrm{AN}>4
\end{array}\right\}
$$

Best-fit equations for SS sub-index:

$$
\mathrm{SI}_{\mathrm{SS}}=\left\{\begin{array}{lr}
97.5 \mathrm{e}^{-0.00676 \mathrm{SS}}+0.05 \mathrm{SS} & \text { for } \mathrm{SS}<100 \\
71 \mathrm{e}^{-0.0016 \mathrm{SS}}-0.015 \mathrm{SS} & \text { for } 100<\mathrm{SS}<1000 \\
0 & \text { for SS }>1000
\end{array}\right\}
$$

Best-fit equations for $\mathrm{pH}$ sub-index:

$$
\mathrm{SI}_{\mathrm{pH}}=\left\{\begin{array}{lr}
17.2-17.2 \mathrm{pH}+5.02 \mathrm{pH}^{2} & \text { for } \mathrm{pH}<5.5 \\
-242+95.5 \mathrm{pH}-6.67 \mathrm{pH}^{2} & \text { for } 5.5<\mathrm{pH}<7 \\
-181+82.4 \mathrm{pH}-6.05 \mathrm{pH}^{2} & \text { for } 7<\mathrm{pH}<8.75 \\
536-77.0 \mathrm{pH}+2.76 \mathrm{pH}^{2} & \text { for } \mathrm{pH}>8.75
\end{array}\right\}
$$




\section{Principal Component Analysis (PCA)}

Principal component analysis was designed to convert a large dataset of original correlated variables into a smaller set of new and uncorrelated variables (i.e. principal components). The data reduction process would provide the most meaningful parameter information that can describe a whole data set with minimum loss of original information (Iscen et al., 2008). The principal components are weighted linear combinations of original variables, with the first principal component representing the largest variability of the original data set, and the second component representing the next largest variance that is orthogonal to the first component (Deb et al., 2008). In other words, PCA can be explained as follows:

$$
z_{i j}=a_{i 1} x_{1 j}+a_{i 2} x_{2 j}+\ldots+a_{i m} x_{m j}
$$

Where $z$ is the component score, $a$ is the component loading, $x$ is the measured value of the variable, $i$ is the component number, $j$ is the sample number, and $m$ is the total number of variables. As stated above, the general procedures used in PCA are (1) the hypothesis in an original data group is then reduced to dominant components or factors (source of variation) that influence the observed data variance; and (2) the whole data set is extracted through eigenvalues and eigenvectors from the square matrix produced by multiplying the data matrix (Aris et al., 2013). In other words, the PCA will undergo varimax rotation to produce the principal components (PCs) before determining the eigenvalue. The eigenvalues of more than 1 are considered significant (Kim and Mueller, 1987) to measure a new group of variables, namely Varimax Factor (VFs). The VFs coefficients that recorded a correlation of greater than 0.75 are considered as 'strong', 0.75 to 0.50 as 'moderate' and 0.50 to 0.30 as 'weak' significant factor (Liu et al., 2006). However, only factor loadings above 0.6 were taken into account for this study. 20 parameter variables will undergo PCA to determine the source of pollutants before hotspot analysis for the dominant source of pollutants in Malacca River.

\section{Spatial Pattern Clustering Through Hotspot Analysis}

Hotspot analysis can be clustered (spatial clusters) or individual (spatial outliers). In this study, spatial cluster of pollution would be water quality with a high value of parameter surrounded by a high value of pollutant sources. Meanwhile, spatial outliers of pollution include water quality with a high value of parameter surrounded by a normal or low value of pollutants source. The concept of hotspot can be expressed as:

$$
G(d)=\frac{\Sigma \Sigma w_{i j}(d) x_{i} x_{j}}{\Sigma \Sigma x_{i} x_{j}}, i \neq j
$$

where $x_{i}$ is the value at location $i, x_{j}$ is the value at location $j$ if $j$ is within $d$ of $i$, and $w_{i j}(\mathrm{~d})$ is the spatial weight based on the weighted distance (e.g. inverse distance) (Getis and Ord, 1992). The expected value of $G(d)$ is:

$$
E(G)=\frac{\sum \sum w_{i j}(d)}{n(n-1)}
$$


where $E(G)$ is typically a very small value when $n$ is large. A high $G(d)$ value suggest a clustering of high values, and a low $G(d)$ value suggests a clustering of low values. $Z$ scores are used to evaluate statistical significance for $G(d)$. In other words, high positive $Z$ scores suggest the presence of a cluster of high values or a hotspot, while high negative of $Z$ scores suggest the presence of a cluster of low value or a cold spot (Figure 2).

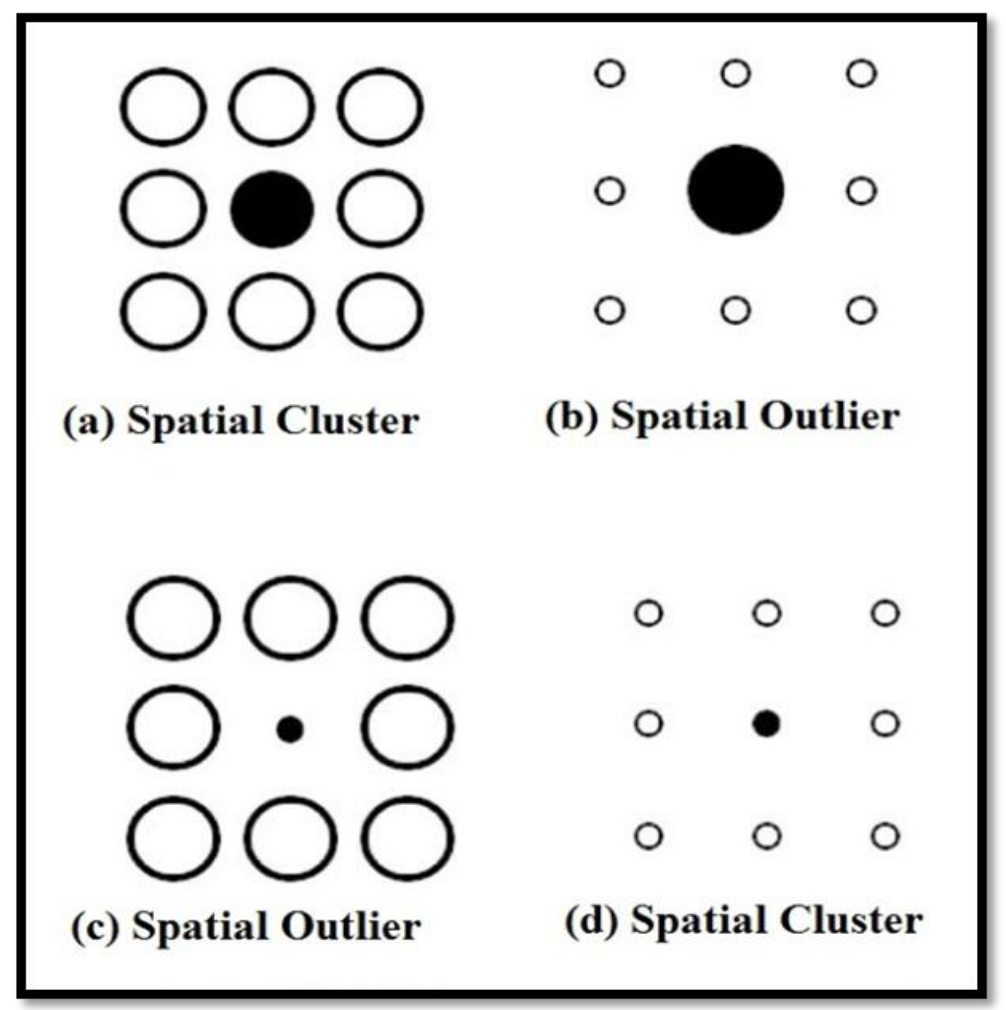

Figure 2. The relationship of a location and its neighborhood; (a) and (b) are hotspot, $(c)$ and (d) are cold spot

\section{Results and Discussion}

\section{Determination of Water Quality Status and WQI in the Malacca River}

Water quality data of Malacca River (i.e. physico-chemical, biological, and trace element data) in comparison with the National Water Quality Standards (NWQS) (Table 3 (i) and (ii) is as shown in Table 4. Based on Table 4, the result indicated that trace elements, together with $\mathrm{pH}$ and temperature, remained as class 1 in all sampling stations. Meanwhile, salinity in station 1 to 3 and station 7, together with turbidity in station 3, 8, and 9, was found to be in class 5. Only station 1 and 5 are in class 3 for turbidity, while other stations remained in class 2 and class 1 in terms of turbidity and salinity, respectively. Station 1 and 7 were found to be in class 5 , station 2 and 3 to be in class 3 , and station 4 to 6 were in class 1 for electrical conductivity and dissolved solids. However, only station 8 and 9 were in class 2 for electrical conductivity, while station 8 was within class 3 and station 9 was in class 1 for dissolved solids. For total suspended solids, most of the stations were classified as class 3, except for station 4, which was in class 4. $\mathrm{BOD}, \mathrm{COD}, \mathrm{DO}$ and $\mathrm{NH}_{3} \mathrm{~N}$, in most of the water samples were classified as 
class 2 and class 3 . However, station 2 and station 7 to 9 showed a class 4 BOD results. This includes $\mathrm{NH}_{3} \mathrm{~N}$ in station 1 to 3 and station 7 to 8 at class 4. Meanwhile, E. coli was classified as class 4 at station 3 and station 6 to 9, while the others were in class 5 . Total coliform was found to be in class 5 for all sampling stations.

According to WQI (Table 2), majority of $\mathrm{NH}_{3} \mathrm{~N}$ and BOD parameters were in class 3, 4 or 5. Meanwhile, COD parameter from station 2 to 7 were in class 3, and others were in class 2. Both DO and TSS parameter showed that only several stations were in class 3. WQI trends showed that the water quality in Malacca River were declining from station 1 to station 7, which show that only station 4 and station 5 were polluted (class 4) while other stations were slightly polluted (class 3). Apart from that, station 8 and station 9 were still in clean condition, which is in class 2 . Therefore, it can be said that all parameters value is affected (either decrease or increase) from the origins. These pollutants which came from human activities could cause problematical issues to the aquatic life in Malacca River.

Table 2. WQI at sampling station in Malacca River sub-basin

\begin{tabular}{|c|c|c|c|c|c|c|c|c|c|c|}
\hline \multirow{2}{*}{$\begin{array}{c}\text { Water } \\
\text { Quality } \\
\text { Parameter }\end{array}$} & \multirow[b]{2}{*}{ Unit } & \multicolumn{9}{|c|}{ Water Sampling Station } \\
\hline & & $\mathrm{S} 1$ & $\mathrm{~S} 2$ & S3 & S4 & S5 & S6 & S7 & S8 & S9 \\
\hline DO & $\mathrm{mg} / \mathrm{L}$ & 4.1 & 5.5 & 3.8 & 3.3 & 4.9 & 8.8 & 9.2 & 7.7 & 6.9 \\
\hline BOD & $\mathrm{mg} / \mathrm{L}$ & 5.0 & 6.0 & 2.0 & 4.0 & 4.0 & 7.0 & 6.0 & 5.0 & 2.0 \\
\hline COD & $\mathrm{mg} / \mathrm{L}$ & 22.0 & 77.0 & 61.0 & 53.0 & 47.0 & 38.0 & 29.0 & 13.0 & 21.0 \\
\hline $\mathrm{AN}$ & $\mathrm{mg} / \mathrm{L}$ & 1.4 & 0.8 & 2.6 & 4.8 & 7.2 & 3.3 & 0.7 & 1.8 & 2.1 \\
\hline TSS & $\mathrm{mg} / \mathrm{L}$ & 45 & 66 & 51 & 83 & 172 & 77 & 43 & 21 & 36 \\
\hline $\mathrm{pH}$ & - & 6.5 & 6.3 & 6.4 & 6.4 & 6.8 & 6.5 & 6.6 & 6.3 & 5.8 \\
\hline \multicolumn{2}{|c|}{ Overall WQI } & 68 & 77 & 62 & 49 & 53 & 66 & 70 & 92 & 88 \\
\hline \multicolumn{2}{|c|}{ Class } & III & III & III & IV & IV & III & III & II & II \\
\hline \multicolumn{2}{|c|}{ Water Quality Status } & $\begin{array}{l}\text { Slightly } \\
\text { Polluted }\end{array}$ & $\begin{array}{l}\text { Slightly } \\
\text { Polluted }\end{array}$ & $\begin{array}{l}\text { Slightly } \\
\text { Polluted }\end{array}$ & Polluted & Polluted & $\begin{array}{l}\text { Slightly } \\
\text { Polluted }\end{array}$ & $\begin{array}{l}\text { Slightly } \\
\text { Polluted }\end{array}$ & Clean & Clean \\
\hline
\end{tabular}

Table 3 (i). National Water Quality Standards for Malaysia (adapted from Malaysian DOE, 2012)

\begin{tabular}{|c|c|c|c|c|c|c|c|}
\hline \multirow{2}{*}{ Category } & \multirow{2}{*}{ Unit } & \multicolumn{6}{|c|}{ Class } \\
\hline & & \multirow{2}{*}{$\begin{array}{c}1 \\
6.5-8.5\end{array}$} & \multirow{3}{*}{$\begin{array}{c}2 \mathrm{~A} \\
6-9 \\
\text { Normal }+2{ }^{\circ} \mathrm{C}\end{array}$} & \multirow{2}{*}{$\begin{array}{c}2 \mathrm{~B} \\
6-9\end{array}$} & \multirow{3}{*}{$\begin{array}{c}3 \\
5-9 \\
\text { Normal }+2^{\circ} \mathrm{C}\end{array}$} & \multirow{2}{*}{$\begin{array}{c}4 \\
5-9\end{array}$} & \multirow{2}{*}{$\begin{array}{l}5 \\
-\end{array}$} \\
\hline $\mathrm{pH}$ & - & & & & & & \\
\hline Temp & ${ }^{\circ} \mathrm{C}$ & - & & - & & - & - \\
\hline Sal & $\%$ & 0.5 & 1 & - & - & 2 & - \\
\hline $\mathrm{EC}$ & $\mu \mathrm{S} / \mathrm{cm}$ & 1000 & 1000 & - & - & 6000 & - \\
\hline TSS & $\mathrm{mg} / \mathrm{L}$ & 25 & 50 & 50 & 150 & 300 & 300 \\
\hline DS & $\mathrm{mg} / \mathrm{L}$ & 500 & 1000 & - & - & 4000 & - \\
\hline Tur & NTU & 5 & 50 & 50 & - & - & - \\
\hline BOD & $\mathrm{mg} / \mathrm{L}$ & 1 & 3 & 3 & 6 & 12 & $>12$ \\
\hline COD & $\mathrm{mg} / \mathrm{L}$ & 10 & 25 & 25 & 50 & 100 & $>100$ \\
\hline DO & $\mathrm{mg} / \mathrm{L}$ & 7 & $5-7$ & $5-7$ & $3-5$ & $<3$ & $<1$ \\
\hline $\mathrm{NH} 3 \mathrm{~N}$ & $\mathrm{mg} / \mathrm{L}$ & 0.1 & 0.3 & 0.3 & 0.9 & 2.7 & $>2.7$ \\
\hline As & $\mathrm{mg} / \mathrm{L}$ & - & 0.05 & 0.05 & $0.4(0.05)$ & 0.1 & - \\
\hline $\mathrm{Hg}$ & $\mathrm{mg} / \mathrm{L}$ & - & 0.001 & 0.001 & $0.004(0.0001)$ & 0.002 & - \\
\hline $\mathrm{Cd}$ & $\mathrm{mg} / \mathrm{L}$ & - & 0.01 & 0.01 & $0.01(0.001)$ & 0.01 & - \\
\hline $\mathrm{Cr}$ & $\mathrm{mg} / \mathrm{L}$ & - & 0.05 & 0.05 & $1.4(0.05)$ & 0.1 & - \\
\hline $\mathrm{Pb}$ & $\mathrm{mg} / \mathrm{L}$ & - & 0.05 & 0.05 & $0.02(0.01)$ & 5 & - \\
\hline $\mathrm{Zn}$ & $\mathrm{mg} / \mathrm{L}$ & - & 1 & 1 & 3.4 & 0.8 & - \\
\hline $\mathrm{Fe}$ & $\mathrm{mg} / \mathrm{L}$ & - & 1 & 1 & 1 & 1(leaf)5(others) & - \\
\hline $\begin{array}{c}\text { Total } \\
\text { Coliform }\end{array}$ & count/100mL & 100 & 5000 & 5000 & $5000(20000)$ & 5000(20000) & $>50000$ \\
\hline Ecoli & count $/ 100 \mathrm{~mL}$ & 10 & 5000 & 5000 & 50000 & 50000 & $>50000$ \\
\hline
\end{tabular}

Tur means Turbidity; DS means Dissolved Solid; Con means Electrical Conductivity; Sal means Salinity; Temp means Temperature; DO means Dissolved Oxygen; BOD means Biological Oxygen Demand; COD means Chemical Oxygen Demand; TSS means Total Suspended Solids; $\mathrm{pH}$ means Acidic or Basic water; $\mathrm{NH}_{3} \mathrm{~N}$ means Ammoniacal Nitrogen; E coli means Escherichia Coliform; Coli means Coliform; As means Arsenic; $\mathrm{Hg}$ means Mercury; Cd means Cadmium; Cr means Chromium; Pb means Lead; Zn means Zinc; Fe means Iron 
Table 3(ii). Water Classes and Uses (adapted from Malaysian DOE, 2012)

\begin{tabular}{|c|l|}
\hline Class 1 & $\begin{array}{l}\text { Conservation of natural environment } \\
\text { Water supply I - Practically no treatment necessary } \\
\text { Fishery - Very sensitive aquatic species }\end{array}$ \\
\hline Class 2A & $\begin{array}{l}\text { Water supply II - Conventional treatment required } \\
\text { Fishery II - Sensitive aquatic species }\end{array}$ \\
\hline Class 2B & Recreational use with body contact \\
\hline Class 3 & $\begin{array}{l}\text { Water supply III - Extensive treatment required } \\
\text { Fishery III - Common of economic value and tolerant species; livestock drinking }\end{array}$ \\
\hline Class 4 & Irrigation \\
\hline Class 5 & None of the above \\
\hline
\end{tabular}

\section{Identification of the Source of Pollutants}

Based on the results of water quality status, it was found that parameters like E-coli, coliform, salinity, turbidity, $\mathrm{NH}_{3} \mathrm{~N}$, and $\mathrm{BOD}$ were in the category of polluted conditions, while several parameters like EC, TSS, DS, COD, and DO were only slightly polluted. Other parameters remained as clean in Malacca River. Therefore, principal component analysis (PCA) was used to identify the source of pollutants that contributed to the pollution in Malacca River. As shown in Table 5, 7 PCs were obtained with eigenvalues more than 1 , with $65 \%$ of total variance. The PC1 loadings with $14.7 \%$ of total variance have strong positive loadings on DS, EC, salinity and $\mathrm{NH}_{3} \mathrm{~N}$. Physico-chemical parameters like DS, EC and salinity may be related to the erosion of riverbank due to dredging activities in the river and agricultural runoff from non-point source pollution (Juahir et al., 2011). The results were coupled with the $\mathrm{NH}_{3} \mathrm{~N}$ pollution together with salinity, highlighting the usage of pesticide for agricultural activities within oil palm and rubber plantations, and animal husbandry (chicken, cow, and goat) carried out within Malacca River basins. These activities contributed to the non-point sources of pollution that occured through surface runoff and water flows through the sub-basins before entering Malacca River. Additionally, PC2 loadings indicated a strong positive in terms of turbidity and TSS with total variance of $9.7 \%$, which can be relate to interruption of human activities towards hydrologic modifications (such as dredging, water diversion, and channelization) that caused disruption in Malacca River (Daneshmand et al., 2011). Other activities like discharge from urban developments through land clearing (USGS, 2010) and surface runoff leading to erosion of road edges (Iscen et al., 2008) could also bring a small amount of pollution to the river. 
Table 4. Mean (and standard deviation) values of water quality data along the Malacca River from in year 2015 ( $n=20)$

\begin{tabular}{|c|c|c|c|c|c|c|c|c|c|c|c|}
\hline Category & Unit & & S1 & S2 & S3 & S4 & S5 & S6 & S7 & S8 & S9 \\
\hline \multirow{2}{*}{$\mathrm{pH}$} & & Mean & 6.50 & 6.43 & 6.46 & 6.46 & 6.55 & 6.49 & 6.64 & 6.40 & 6.33 \\
\hline & - & SD & 0.34 & 0.28 & 0.31 & 0.43 & 0.21 & 0.31 & 0.35 & 0.34 & 0.47 \\
\hline \multirow{2}{*}{ Temp } & & Mean & 27.19 & 26.89 & 26.88 & 26.63 & 26.59 & 26.86 & 27.62 & 27.49 & 28.33 \\
\hline & ${ }^{\circ} \mathrm{C}$ & SD & 0.87 & 1.13 & 0.81 & 0.97 & 0.72 & 1.01 & 0.83 & 1.06 & 0.72 \\
\hline \multirow{2}{*}{ Sal } & $\%$ & Mean & 21.04 & 9.39 & 4.00 & 0.51 & 0.07 & 0.05 & 7.00 & 0.31 & 0.06 \\
\hline & $\%$ & SD & 9.78 & 3.50 & 3.32 & 0.44 & 0.03 & 0.02 & 8.71 & 0.27 & 0.04 \\
\hline \multirow{2}{*}{$\mathrm{EC}$} & $\mathrm{S} / \mathrm{cm}$ & Mean & 16330.22 & 1403.73 & 1950.72 & 280.43 & 218.37 & 109.60 & 8173.90 & 1069.33 & 1093.83 \\
\hline & $\mu \mathrm{S} / \mathrm{cm}$ & SD & 12329.04 & 1067.37 & 1366.13 & 154.04 & 98.45 & 29.72 & 11118.65 & 459.17 & 630.46 \\
\hline \multirow{2}{*}{ TSS } & & Mean & 51.08 & 38.75 & 59.83 & 116.17 & 97.67 & 75.08 & 50.75 & 44.75 & 67.00 \\
\hline & $\mathrm{mg} / \mathrm{L}$ & SD & 15.81 & 11.62 & 16.52 & 97.40 & 65.00 & 63.98 & 50.71 & 13.84 & 20.68 \\
\hline \multirow{2}{*}{ DS } & & Mean & 10444.61 & 1095.07 & 952.03 & 326.90 & 81.20 & 77.22 & 6257.26 & 505.89 & 223.00 \\
\hline & $\mathrm{mg} / \mathrm{L}$ & $\mathrm{SD}$ & 7745.21 & 592.67 & 441.54 & 174.31 & 18.08 & 17.75 & 8716.84 & 214.39 & 136.15 \\
\hline \multirow{2}{*}{ Tur } & & Mean & 116.70 & 73.61 & 584.57 & 99.86 & 121.18 & 84.85 & 63.62 & 297.77 & 209.71 \\
\hline & NTU & SD & 67.18 & 29.59 & 494.93 & 70.09 & 65.26 & 30.01 & 47.17 & 128.61 & 276.70 \\
\hline \multirow{2}{*}{ BOD } & & Mean & 5.08 & 6.50 & 4.50 & 5.17 & 5.33 & 5.17 & 6.50 & 9.25 & 6.58 \\
\hline & $\mathrm{mg} / \mathrm{L}$ & SD & 1.93 & 2.78 & 0.90 & 1.27 & 1.07 & 0.72 & 1.31 & 2.09 & 2.84 \\
\hline \multirow{2}{*}{$\mathrm{COD}$} & $\mathrm{mo} / \mathrm{I}$ & Mean & 34.17 & 47.17 & 33.25 & 24.00 & 23.92 & 24.33 & 27.58 & 46.25 & 24.67 \\
\hline & & $\mathrm{SD}$ & 11.90 & 27.43 & 11.45 & 11.76 & 7.25 & 5.30 & 8.71 & 16.97 & 6.62 \\
\hline \multirow{2}{*}{ DO } & & Mean & 4.11 & 4.16 & 3.89 & 5.02 & 5.61 & 5.12 & 3.35 & 5.54 & 5.53 \\
\hline & $\mathrm{mg} / \mathrm{L}$ & SD & 0.88 & 1.53 & 1.46 & 1.42 & 0.97 & 1.01 & 1.24 & 2.19 & 0.86 \\
\hline \multirow{2}{*}{ NH3N } & & Mean & 0.99 & 1.08 & 1.42 & 0.77 & 0.52 & 0.68 & 2.39 & 1.76 & 0.65 \\
\hline & $\mathrm{mg} / \mathrm{L}$ & SD & 0.47 & 0.50 & 1.07 & 0.21 & 0.28 & 0.41 & 1.70 & 0.78 & 0.20 \\
\hline \multirow{2}{*}{ As } & & Mean & 0.0038 & 0.0040 & 0.0022 & 0.0026 & 0.0015 & 0.0022 & 0.0028 & 0.0037 & 0.0038 \\
\hline & $\mathrm{mg} / \mathrm{L}$ & SD & 0.00426 & 0.00529 & 0.00147 & 0.00144 & 0.00080 & 0.00134 & 0.00119 & 0.00098 & 0.00204 \\
\hline \multirow{2}{*}{$\mathrm{Hg}$} & & Mean & 0.0002 & 0.0002 & 0.0002 & 0.0002 & 0.0002 & 0.0002 & 0.0003 & 0.0002 & 0.0002 \\
\hline & $\mathrm{mg} / \mathrm{L}$ & $\mathrm{SD}$ & 0.00003 & 0.00009 & 0.00003 & 0.00000 & 0.00012 & 0.00000 & 0.00018 & 0.00000 & 0.00003 \\
\hline \multirow[b]{2}{*}{$\mathrm{Cd}$} & & Mean & 0.0010 & 0.0010 & 0.0010 & 0.0010 & 0.0010 & 0.0010 & 0.0010 & 0.0010 & 0.0010 \\
\hline & $\mathrm{mg} / \mathrm{L}$ & SD & 0.00000 & 0.00000 & 0.00000 & 0.00000 & 0.00000 & 0.00000 & 0.00000 & 0.00000 & 0.00000 \\
\hline \multirow{2}{*}{$\mathrm{Cr}$} & & Mean & 0.0016 & 0.0023 & 0.0017 & 0.0012 & 0.0011 & 0.0011 & 0.0011 & 0.0033 & 0.0011 \\
\hline & $\mathrm{mg} / \mathrm{L}$ & SD & 0.00151 & 0.00372 & 0.00161 & 0.00035 & 0.00029 & 0.00029 & 0.00029 & 0.00444 & 0.00029 \\
\hline \multirow{2}{*}{$\mathrm{Pb}$} & & Mean & 0.0100 & 0.0100 & 0.0100 & 0.0100 & 0.0100 & 0.0100 & 0.0100 & 0.0100 & 0.0100 \\
\hline & $\mathrm{mg} / \mathrm{L}$ & $\mathrm{SD}$ & 0.00000 & 0.00000 & 0.00000 & 0.00035 & 0.00000 & 0.00000 & 0.00000 & 0.00000 & 0.00000 \\
\hline \multirow{2}{*}{$\mathrm{Zn}$} & & Mean & 0.06 & 0.05 & 0.06 & 0.05 & 0.05 & 0.05 & 0.04 & 0.05 & 0.06 \\
\hline & $\mathrm{mg} / \mathrm{L}$ & SD & 0.02 & 0.02 & 0.02 & 0.03 & 0.02 & 0.02 & 0.02 & 0.02 & 0.02 \\
\hline \multirow[b]{2}{*}{$\mathrm{Fe}$} & & Mean & 0.48 & 0.40 & 0.56 & 1.15 & 0.88 & 1.14 & 0.36 & 0.79 & 0.89 \\
\hline & $\mathrm{mg} / \mathrm{L}$ & SD & 0.41 & 0.36 & 0.37 & 0.81 & 0.44 & 1.03 & 0.28 & 0.60 & 0.13 \\
\hline \multirow{2}{*}{$\begin{array}{c}\text { Total } \\
\text { Coliform }\end{array}$} & & Mean & 698366.67 & 584866.67 & 701375.00 & 1005583.33 & 571808.33 & 656116.67 & 155958.33 & 117783.33 & 161558.33 \\
\hline & count $/ 100 \mathrm{~mL}$ & SD & 510510.49 & 198044.61 & 448855.58 & 865227.40 & 340474.95 & 244295.76 & 107181.10 & 74326.53 & 94999.84 \\
\hline \multirow{2}{*}{ Ecoli } & count $100 \mathrm{~m}$ & Mean & 71275.00 & 63275.00 & 40358.33 & 17317.33 & 571808.33 & 20766.67 & 13745.00 & 14829.17 & 11455.83 \\
\hline & count $/ 100 \mathrm{~mL}$ & SD & 33664.63 & 32261.69 & 43663.93 & 22922.74 & 340474.95 & 35458.43 & 6812.92 & 6701.57 & 7260.65 \\
\hline
\end{tabular}

Tur means Turbidity; DS means Dissolved Solid; Con means Electrical Conductivity; Sal means Salinity; Temp means Temperature; DO means Dissolved Oxygen; BOD means Biological Oxygen Demand; COD Arsenic; Hg means Mercury; Cd means Cadmium; Cr means Chromium; Pb means Lead; Zn means Zinc; Fe means Iron; SD means Standard Deviation; S1 to S9 means Station 1 to Station 9 
On the other hand, PC3 loadings explained BOD loadings and COD loadings as moderately positive with $9.4 \%$ of total variance, which might be connected to anthropogenic activities and point source pollution like sewage treatment plants and industrial effluents (Juahir et al., 2011). Meanwhile, PC4 explaining E-coli loadings, coliform loadings, and $\mathrm{pH}$ loadings showed a moderate positive with $8.9 \%$ of total variance. The presence of E-coli and coliform indicated that animal husbandry, sewage treatment plant, and municipal wastes contributed to point source pollution in the river. This situation has caused the river water to absorb a large amount of oxygen and hence decreases the availability of DO, which indirectly underwent the anaerobic fermentation processes to produce ammonia and organic acid (Juahir et al., 2011). Consequently, acidic materials through hydrolysis have caused the water $\mathrm{pH}$ to decrease drastically. Next, PC5 explained moderate positive loadings on $\mathrm{Zn}$ and $\mathrm{Fe}$ with $8.4 \%$ of total variance. The $\mathrm{Zn}$ pollution can be linked to the large number of houses and building in the area that uses metallic roofs coated with $\mathrm{Zn}$, which can mobilize into the atmosphere and waterways during acid rain or smog (Juahir et al., 2011), while Fe pollution can be attributed to metal group originating from industrial effluents (Aris et al., 2013). PC6 and PC7 loadings showed moderately positive $\mathrm{Cr}$ and $\mathrm{Hg}$ loadings having total variance of $7.4 \%$ and $6.4 \%$ respectively. Cr pollution can be linked to urban storm runoff (Juahir et al., 2011), and $\mathrm{Hg}$ pollution were suspected to link with plastic and chemical industrial wastewater (Papaioannou et al., 2010). Therefore, based on PCA analysis, 5 categories of pollutant sources were identified, namely agricultural activities, municipal and commercial residential activities, industrial activities, animal husbandry activities, as well as sewage treatment plant.

\section{Classification of dominant pollutant sources}

GIS Hotspot analysis was used to determine the dominant pollutant sources, which have been identified from PCA, namely agricultural, residential, industrial, and animal husbandry activities, as well as a sewage treatment plant, as shown in Figure 3. As described previously, $Z$ score was used to evaluate the statistical significance for the variable in hotspot analysis. High positive $Z$ scores suggest the presence of a cluster of high values or hotspots, while high negative $Z$ scores suggest the presence of a cluster of low value or cold spot. For agricultural activity, the variable produced a general Gstatistic of 0.0 and a $Z$ score of 37.31, suggesting a spatial clustering of high value of 0.01 significant levels. Secondly, the residential variable has general G-statistic of 0.0 and a $\mathrm{Z}$ score of 74.72, with spatial clustering at a high value of 0.01 significant levels. Industrial variable indicated a general G-statistic of 0.0 and a $\mathrm{Z}$ score of 13.5 and suggested spatial clustering of high value of 0.01 significant levels., Animal husbandry activity showed general G-statistic of 0.0 with a $\mathrm{Z}$ score of -1.08 , suggesting a spatial clustering of low values towards 0.10 significant levels. On the other hand, sewage treatment plant showed no value in general G-statistic and Z score, indicated that there are no significant level at the random value. Lastly, open space variable recorded a general G-statistic of 0.0 with a $\mathrm{Z}$ score of 28.73 indicating a high value of spatial clustering of 0.01 significant levels. All $\mathrm{Z}$ scores of selected variables were incorporated into GIS mapping to determine the dominant pollutant sources through hotspot analysis (Figure 3). 
Table 5. Varimax rotation PCs for water quality in Malacca River basin

\begin{tabular}{|c|c|c|c|c|c|c|c|}
\hline \multirow[t]{2}{*}{ Variables (Unit) } & \multicolumn{7}{|c|}{ Principle Components } \\
\hline & 1 & 2 & 3 & 4 & 5 & 6 & 7 \\
\hline Turbidity (NTU) & -.104 & .868 & .016 & .060 & -.014 & -.003 & -.045 \\
\hline Dissolved Solid (mg/L) & .809 & .027 & .014 & .076 & -.128 & .156 & -.057 \\
\hline Electrical Conductivity (uS) & .859 & .028 & .003 & .142 & -.045 & -.025 & -.014 \\
\hline Salinity (ppt) & .808 & -.075 & -.212 & -.124 & .252 & -.005 & -.097 \\
\hline Temperature $\left({ }^{\circ} \mathrm{C}\right)$ & .167 & .171 & -.204 & -.384 & .027 & -.307 & -.053 \\
\hline Dissolved Oxygen (mg/L) & -.367 & -.283 & .305 & .415 & .203 & -.218 & -.346 \\
\hline $\begin{array}{l}\text { Biological Oxygen Demand } \\
(\mathrm{mg} / \mathrm{L})\end{array}$ & -.009 & .049 & .629 & .095 & .466 & .334 & .010 \\
\hline $\begin{array}{l}\text { Chemical Oxygen Demand } \\
(\mathrm{mg} / \mathrm{L})\end{array}$ & -.056 & .199 & .609 & .048 & -.087 & .022 & -.070 \\
\hline $\begin{array}{l}\text { Total Suspended Solid } \\
(\mathrm{mg} / \mathrm{L})\end{array}$ & -.193 & .826 & -.069 & -.092 & -.194 & -.013 & -.185 \\
\hline Acidity/Alkalinity $(\mathrm{pH})$ & .081 & .217 & -.087 & .745 & -.201 & .008 & -.169 \\
\hline $\begin{array}{l}\text { Ammociacal Nitrogen } \\
(\mathrm{mg} / \mathrm{L})\end{array}$ & .831 & 0.32 & .011 & .157 & .128 & -.010 & .116 \\
\hline E-coli (cfu/100ml) & .533 & -.048 & -.124 & .652 & .359 & -.108 & .124 \\
\hline Coliform (cfu/100ml) & .027 & .032 & .293 & .603 & .096 & -.192 & -.221 \\
\hline Arsenic (mg/L) & .243 & -.174 & -.263 & .011 & .392 & -.072 & .047 \\
\hline Mercury (mg/L) & -.068 & -.155 & -.063 & -.050 & -.022 & .065 & .787 \\
\hline Chromium (mg/L) & .030 & -.174 & .037 & .086 & .322 & .662 & .267 \\
\hline Zinc (mg/L) & .146 & .314 & .014 & -.091 & .712 & -.066 & .156 \\
\hline Iron $(\mathrm{mg} / \mathrm{L})$ & -.114 & -.258 & -.051 & -.068 & .658 & .028 & .043 \\
\hline Initial Eigenvalue & 2.650 & 1.751 & 1.692 & 1.609 & 1.517 & 1.336 & 1.157 \\
\hline$\%$ of Variance & 14.723 & 9.729 & 9.398 & 8.939 & 8.427 & 7.422 & 6.430 \\
\hline Cumulative $\%$ & 14.723 & 24.452 & 33.850 & 42.788 & 51.215 & 58.637 & 65.066 \\
\hline
\end{tabular}

*The bold values are factor loadings above 0.60 that were taken after Varimax rotation are performed

Figure 3 (a) indicated the agricultural activities weighted concentration that concentrated in Kampung Tualang sub-basin (S5), which can be described as a hot spot area. The existence of a hot spot area in S5 sub-basin is due to the ease of access to water resources from Durian Tunggal Reservoirs. Indirectly, pesticide and chemical substances used for agricultural activities would enter surface runoff during the wet season. The water would flow into a nearby sub-basin before entering Malacca River. These processes contributed to the non-point source pollution. As shown in Figure $3(b)$ residential activities shows that the high values are concentrated in Kampung Kelemak sub-basin (S1), Kampung Sungai Petai sub-basin (S2), Kampung Cheng sub-basin (S6), Kampung Batu Berendam sub-basin (S7), and a little bit at Kampung Tualang sub-basin (S5). There is also a highly weighted concentration located parallel to the Malacca River from S1 to S5. Only moderate values are shown along S6 to S9. Hence, residential activities showed that almost every sub basin is a hot spot area and hence it is a 
significant to contributor of pollution to the river. This situation may be related to the rapid and uncontrolled development, drastically increasing population, and unmanageable land clearing that brought pollution through wash water and cooking waste, municipal waste, and commercial waste as well as metallic roof pollution.

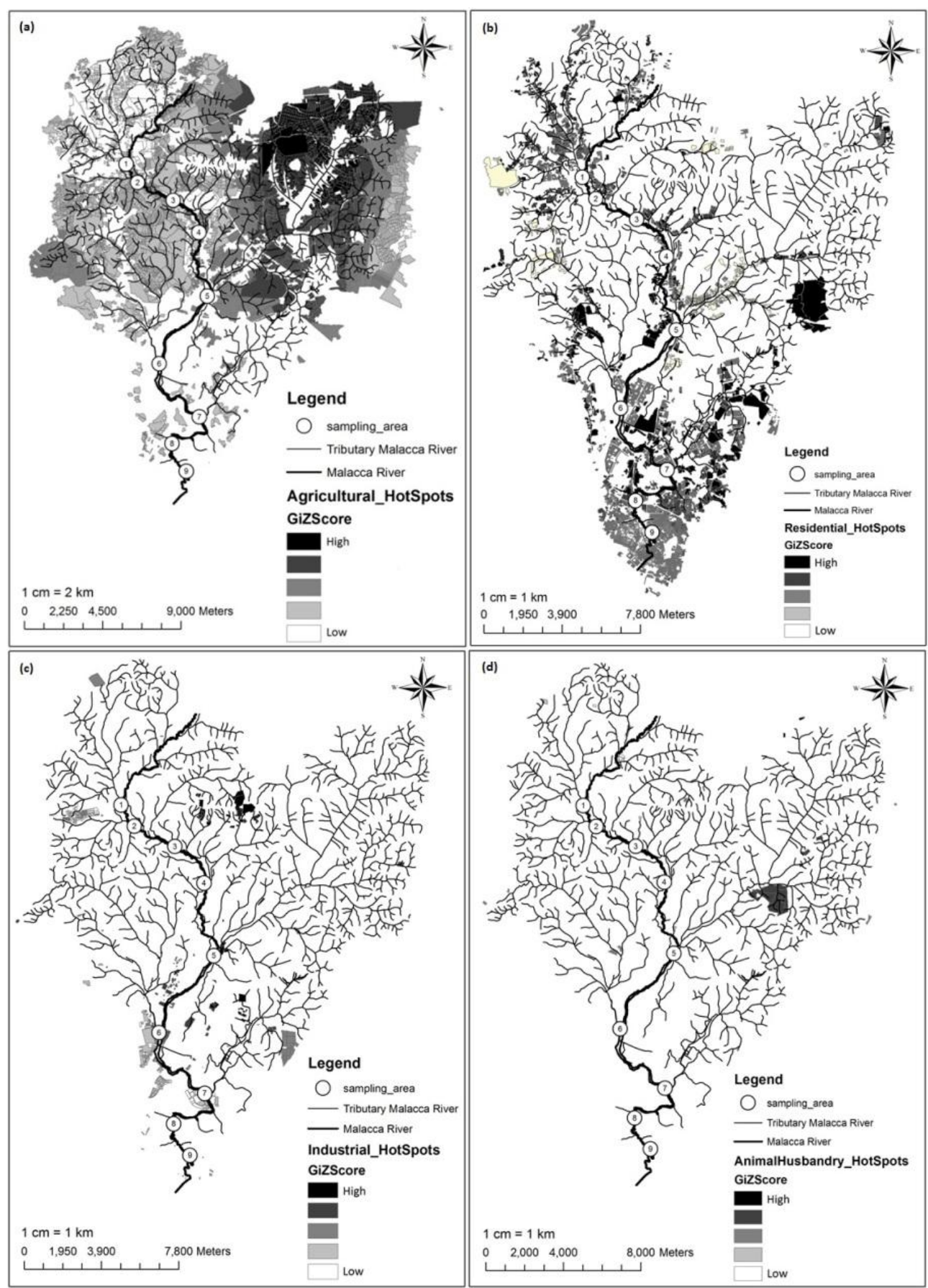




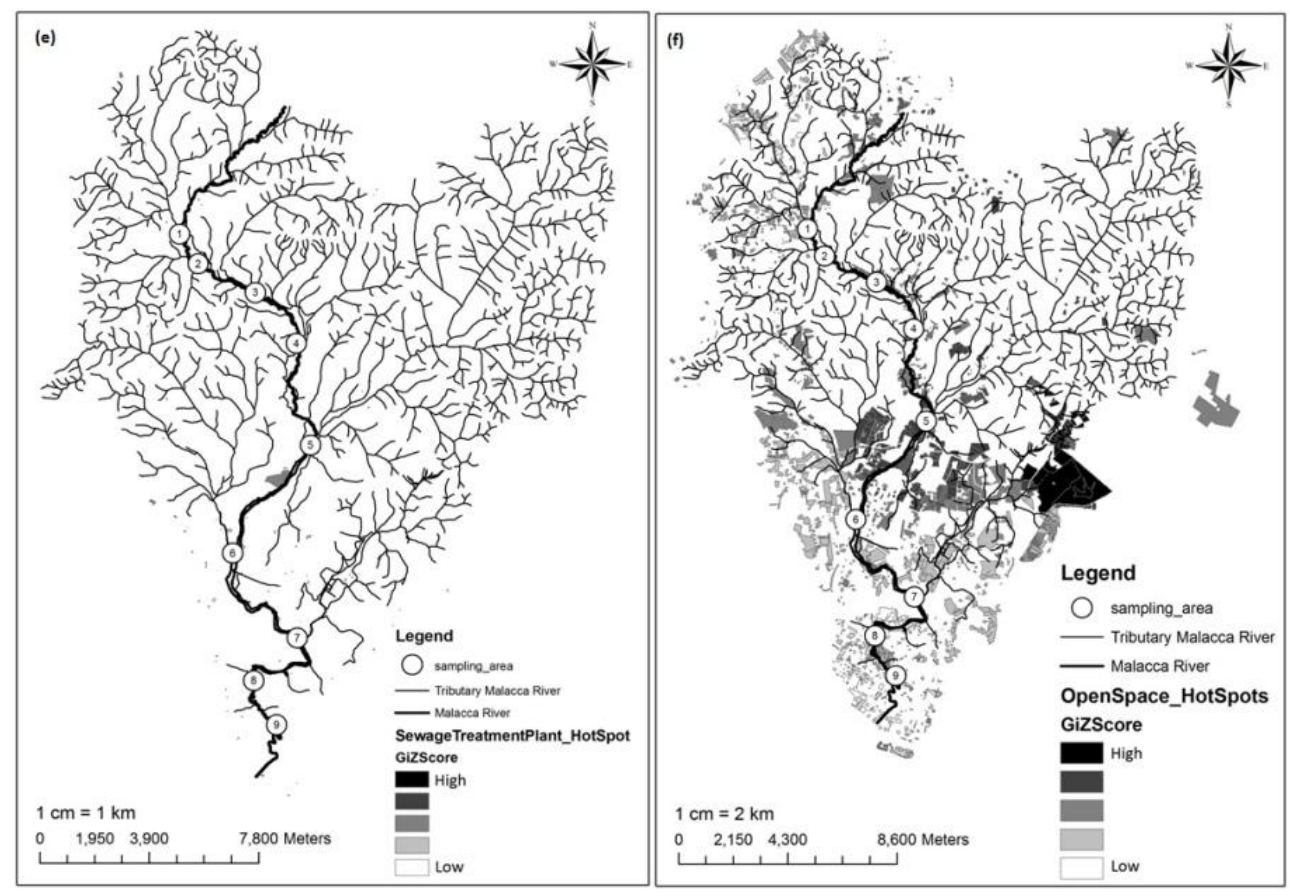

Figure 3. Hotspot analysis of Pollutant Sources - (a) Agriculture; (b) Residential; (c) Industrial; (d) Animal Husbandry; (e) Sewage Treatment Plant; ( $f$ ) Open Space

Next, hot spot areas from industrial activities (Figure $3(c)$ ) have been detected in Kampung Panchor sub-basin (S3), Harmoni Belimbing Dalam sub-basin (S4), Kampung Tualang sub-basin (S5), and Kampung Batu Berendam sub-basin (S7). Hightechnology and estate industries are the main contributors to point source pollution due to the direct discharge into sub basins before flowing into the main river. It is compulsory for industrial wastes to undergo treatment before being release onto surface water or in a river; however, certain industries refused to do so in order to save cost and time. Hence, these action increases the potential of hot spot area to pollute Malacca River sub-basins. Animal husbandry activities (refer to Figure $3(d)$ ) shows a moderate hot spot area at Kampung Tualang sub-basin (S5) and several hot spots are scattered in sampling 1 to sampling 4 sub-basin, while the sewage treatment plant has a moderate hot spot area between S5 and S6 while others are scattered in S1 sub-basin and S6 to S9 sub-basins, respectively. Since animal husbandries are highlighted within a S5 subbasin, this condition demonstrates that the activity is carried out in the area adjacent to Durian Tunggal Reservoirs as it is easier to obtain freshwater to feed the animals. However, unmanageable cleanliness within the farms led to animal feces flowing into the river through surface run-off, which contributed to the non-point source pollution. Sewage treatment plants that are scattered in downstream area can be clarified as low impact in terms of pollution in Malacca River, but they have a high chance to cause pollution if there is a malfunction that may lead to leakage (Figure 3(e)).

The open space variable shows a high value at Kampung Tualang sub-basin (S5) to act as a hot spot area, while moderate values were detected in S1 sub-basin and S6 to S8 sub-basins as shown in Figure $3(f)$. Several moderate hot spot areas also exist along Malacca River, from sampling 1 to sampling 6 . The main reason to have the open space variable in this study is to reduce river water pollution by controlling the pollutant source. This suggestion may be proposed to government sector agencies such as the 
Department of Environmental (DOE), Department of Irrigation and Drainage (JPS) and other departments that concerns with river water quality to build a monitoring system so that easi and frequent monitor of the water status could be done. At the same time, researchers and academicians may take the opportunity to develop studies on river water quality perspectives for a better environment.

\section{Conclusion}

This study has proven that PCA and GIS are remarkable and useful tools to discover the influential factors involved in Malacca River water quality. This study also revealed that sampling station 5 located in Kampung Tualang sub basin is considered to be the main area to cause pollution to the river through the dominant sources of pollutant from the agricultural, residential, industrial activities, and animal husbandry. Continuous exposure to pollutant sources concentration could pose a serious threat to the river's ecosystem in the present and future timeframe. Frequent assessment and monitoring is crucial for the continuous protection of Malacca River ecosystem. Therefore, this study does not only suggest the reduction of river water pollution by means of controlling the pollutant sources, but also by providing information which identifies the problematic areas for better management and understanding of the river water quality in the future. The study also provides a spatial database through GIS mapping for future reference for the development of proper land use and urban design procedures.

Acknowledgements. The authors would like to thank the Department of Environment (DOE) Malaysia, Department of Irrigation and Drainage (JPS) Malaysia, and Department of Town and Country Planning (JPBD) Malaysia for providing the base data for water quality, river, and GIS-map based maps including land use activities.

\section{REFERENCES}

[1] Al-Shami, S. A., Rawi, C. S. M., HassanAhmad, A., Nor, S. A. M. (2010): Distribution of Chironomidae (Insecta: Diptera) in polluted rivers of the Juru River Basin, Penang, Malaysia. - Journal of Environmental Sciences 22(11): 1718-1727.

[2] APHA (2005). Standard methods for the examination of water and wastewater, $21^{\text {st }}$ ed. American Water Works Association, Water Environment Federation, Washington.

[3] Aris, A. Z., Praveena, S. M., Isa, N. M., Lim, W. Y., Juahir, H., Yusoff, M. K., Mustapha, A. (2013): Application of environmetric methods to surface water quality assessment of Langkawi Geopark (Malaysia). - Environmental Forensics 14(3): 230-239.

[4] Cliff, A. D., Ord, J. K. (1981): Spatial processes: models \& applications (Vol. 44). London: Pion.

[5] Daneshmand, S., Huat, B. B., Moayedi, H., Ali, T. A. M. (2011): Study on water quality parameters of Linggi and Melaka rivers catchments in Malaysia. - Engineering Journal 15(4): 41-52.

[6] Davis, A. P., McCuen, R. H. (2005): Storm water management for smart growth, $1^{\text {st }}$ ed. Springer Science and Business Media.

[7] Deb, D., Deshpande, V. N., Das, K. C. (2008): Assessment of water quality around surface coal mines using principal component analysis and fuzzy reasoning techniques. Mine Water and the Environment 27(3): 183-193.

[8] DOE (2012). Malaysia Environmental Quality Report 2012. - Department of Environment, Ministry of Natural Resources and Environment, Kuala Lumpur, Malaysia. 
[9] Ebrahimpour, M., Mushrifah, I. (2008): Heavy metal concentrations in water and sediments in Tasik Chini, a freshwater lake, Malaysia. - Environmental monitoring and assessment 141(1-3): 297-307.

[10] Getis, A., Ord, J. K. (1992): The analysis of spatial association by use of distance statistics. - Geographical analysis 24(3): 189-206.

[11] Houser, J. N., Richardson, W. B. (2010): Nitrogen and phosphorus in the Upper Mississippi River: transport, processing, and effects on the river ecosystem. Hydrobiologia 640(1): 71-88.

[12] Hua, A. K. (2015): Law Enforcement and Water Resources of the Malacca River A Case Study of Public Perception. - International Journal of Scientific Research in Science \& Technology 3 (1): 111-116.

[13] Iscen, C. F., Emiroglu, Ö., Ilhan, S., Arslan, N., Yilmaz, V., Ahiska, S. (2008): Application of multivariate statistical techniques in the assessment of surface water quality in Uluabat Lake, Turkey. - Environmental monitoring and assessment 144(1-3): 269-276.

[14] Ishioka, F., Kurihara, K., Suito, H., Horikawa, Y., Ono, Y. (2007): Detection of hotspots for three-dimensional spatial data and its application to environmental pollution data. Journal of Environmental Science for Sustainable Society 1: 15-24.

[15] Juahir, H., Zain, S. M., Yusoff, M. K., Hanidza, T. T., Armi, A. M., Toriman, M. E., Mokhtar, M. (2011): Spatial water quality assessment of Langat River Basin (Malaysia) using environmetric techniques. - Environmental monitoring and assessment 173(1-4): 625-641.

[16] Kim, J. O., Mueller, C. W. (1987): Introduction to factor analysis: what it is and how to do it. Quantitative applications in the social sciences series. - Park: Sage University Press.

[17] Li, S., Zhang, Q. (2010): Spatial characterization of dissolved trace elements and heavy metals in the upper Han River (China) using multivariate statistical techniques. - Journal of Hazardous Materials, 176(1): 579-588.

[18] Liu, X., Wu, J., Xu, J. (2006). Characterizing the risk assessment of heavy metals and sampling uncertainty analysis in paddy field by geostatistics and GIS. Environmental Pollution 141(2): 257-264.

[19] Mahvi, A. H. Razazi, M. (2005): Application of polyelectrolyte in turbidity removal from surface water. - Am. J. Appl. Sci. 2: 397.

[20] McLaughlin, C. C., Boscoe, F. P. (2007): Effects of randomization methods on statistical inference in disease cluster detection. - Health \& Place 13(1): 152-163.

[21] Metro Online. Sampel air sungai dianalisis. Downloaded: April 23, 2015. Retrieved from http://www.hmetro.com.my/node/45800?m=1

[22] Morse, N. B., Wollheim, W. M. (2014). Climate variability masks the impacts of land use change on nutrient export in a suburbanizing watershed. - Biogeochemistry 121(1): 4559.

[23] Muyibi, S. A., Ambali, A. R., Eissa, G. S. (2008): The impact of economic development on water pollution: Trends and policy actions in Malaysia. - Water resources management 22(4): 485-508.

[24] Odland, J. (1988): Spatial Autocorrelation. - California: Sage Publications, 87.

[25] Papaioannou, A., Mavridou, A., Hadjichristodoulou, C., Papastergiou, P., Pappa, O., Dovriki, E., Rigas, I. (2010): Application of multivariate statistical methods for groundwater physicochemical and biological quality assessment in the context of public health. - Environmental monitoring and assessment 170(1-4): 87-97.

[26] Shin, J. Y., Artigas, F., Hobble, C., Lee, Y. S. (2013): Assessment of anthropogenic influences on surface water quality in urban estuary, northern New Jersey: multivariate approach. - Environmental monitoring and assessment 185(3): 2777-2794. 
[27] Shrestha, S., Kazama, F. (2007): Assessment of surface water quality using multivariate statistical techniques: A case study of the Fuji river basin, Japan. - Environmental Modelling \& Software 22(4): 464-475.

[28] Sinar Harian Online. Kurang oksigen punca ikan mati di Sungai Melaka. Accessed on January 1, 2016. Retrieved from http://www.sinarharian.com.my/edisi/melaka-ns/kurangoksigen-puncaikan-mati-di-sungai-melaka-1.467732

[29] Singh, K. P., Basant, N., Gupta, S. (2011): Support vector machines in water quality management. - Analytica Chimica Acta 703(2): 152-162.

[30] Suratman, S., Hang, H. C., Shazili, N. A. M., Tahir, N. M. (2009): A preliminary study of the distribution of selected trace metals in the Besut River basin, Terengganu, Malaysia. Bulletin of environmental contamination and toxicology 82(1): 16-19.

[31] Tango, T. (1995): A class of tests for detecting 'general'and 'focused'clustering of rare diseases. - Statistics in Medicine 14(21-22): 2323-2334.

[32] UNESCO Official Portal (2016). Melaka and George Town, Historic Cities of the Straits of Malacca. Retrieved from http://whc.unesco.org/en/list/1223

[33] U.S. Geological Survey (USGS) (1999). The quality of our nation's water-nutrients and pesticides. U.S. Geological Survey Circular 1225.

[34] Wang F., Ding Y., Ge, L., Ren, H., Ding, L. (2010): Effect of high-strength ammonia nitrogen acclimation on sludge activity in sequencing batch reactor. - J. Environ. Sci. 22 (11): 1683 .

[35] WSDE (Washington State Department of Ecology) (2002). Setting standards for the bacteriological quality of Washington's surface water. - Draft discussion paper and literature summary, Publication No. 00-10-072. Washington DC.

[36] Zhang, C., Luo, L., Xu, W., Ledwith, V. (2008): Use of local Moran's I and GIS to identify pollution hotspots of $\mathrm{Pb}$ in urban soils of Galway, Ireland. - Science of the Total Environment 398(1): 212-221.

[37] Zhang, C. (2006): Using multivariate analyses and GIS to identify pollutants and their spatial patterns in urban soils in Galway, Ireland. - Environmental pollution 142(3): 501511.

[38] Zhang, T., Lin, G. (2006): A Supplemental Indicator of High-Value or Low-Value Spatial Clustering. - Geographical Analysis 38(2): 209-225. 